DOI: https://doi.org/10.32839/2304-5809/2020-4-80-90

UDC 347.7

Rza Mustafayev Vagif

Vytautas Magnus University

\title{
SHAREHOLDER PRIMACY: EN ROUTE TO PARADIGM SHIFT
}

Summary. The article is built upon the ever-going debate of finding the true purpose of companies in our modern-day world, an equitable form of corporate governance and balancing the interests between various stakeholders. The study goes through the new paradigm shift regarding the corporate governance and the real risk positioning of each stakeholder. It demonstrates that there is an ongoing process that will change that understanding of companies as profit-making instruments to distribute and enrich their shareholders. It shows the explicit flaws in shareholder primacy theory by stating the cases when it was the reason standing behind corporate misbehavior and catastrophes.

Keywords: stakeholders, social responsibility, business, company, liability, sustainability.

Tntroduction. A role of balanced and well-designed corporate governance for the development of the company, regardless private or public, and as well its positive impact on the outside world can hardly be questioned. Establishing and enforcing thoughtful policies can promote the well-being of shareholders, create a positive image of the firm, reduce expenditures, attract new investment and face a positive response by employees, therefore, increasing the efficiency of the firm. Moreover, by pursuing the interests of correct parties in the company, corporate managers widen the possibilities of the firm and guarantee its sustainable development. Corporate governance is able to spread doubt on a company's reliability, integrity or commitment to shareholders all of which adversely affects firm's financial health.

Corporate governance is a relatively young discipline passing a long way of success and failures. It is still on the phase of active development and will hardly stop changing. Two major approaches, namely shareholder value and stakeholder value, to corporate governance exist. While acting in the best interests of shareholders, advancing their well-being, increasing dividend payments and capital gains are the main features of shareholder value, the latter one suggests creating value for all stakeholders of the firm. Each of the concepts has its own merits and demerits, which gives rise to a great range of studies, practical and theoretical outcomes. As it is seen, the main party who is central for both concepts are shareholders. The important distinguishing question between shareholder value and stakeholder value is whether corporate governance should be inclined toward shareholder interests or balance them with common interests.

Most simply, a shareholder can be defined as a person holding stock in the company. For a long period of time shareholder value theory has dominated in the corporate governance and shareholder interests were put above other interests within the company. The view arose from assumptions ranging from 'shareholders are residual claimants' to 'shareholders are the owners of the company'.

However, the expansion of shareholder value theory does not happen; a lot of studies are done to improve corporate governance. Mass media shares dozens of corporate misbehaviour cases followed by immense societal and environmental harm, lawsuits of billions of monetary damages and destroyed reputation of the huge multinational companies. The gradual shift from shareholder value to stakeholder value theory and abandoning the idea of the sole financial function of businesses is the main feature of modern-day corporate governance. The question challenging the accountability of inferiority of shareholders in terms of bargaining arises.

Research object: theoretical and case studies concerning the corporate governance, shareholder primacy and stakeholder value.

Research aim: the study is aimed to reveal modern trends in corporate governance in terms of current paradigm shift from shareholder primacy.

\section{Research objectives:}

1. Analyzing the history behind shareholder primacy.

2. Determining justifications for shareholder primacy.

3. Identifying their inefficiency and true picture of fair corporate governance.

1.1. Shareholder primacy: definition and dominance

The notion of corporation is obviously one of the main institutional creations of industrial capitalism, which has been contributing, in the form it has taken from the late nineteenth century, to reshape economy and society dramatically. As was noted by plenty of lawyers, economists, and researchers in the field of corporate law, the corporation has been the vital instrument of advancing the world economy. The economic, social, environmental, and even political impacts of the actions by the big companies are today, more than ever, of tremendous significance. Many of them are capable of making profits calculated is billions, such as Walmart with \$514.405B in 2019 [1], or Royal Dutch Shell with 388.38 in 2018 [13]. Millions of employees are engaged on daily operations. 1.5 million employees work in McDonald's restaurants, while Amazon stands out with 600.000 employees [4]. Some of the companies are not politically inactive as well. Millions of USD are spent every year since 2010 in the form of donations by big companies [8]. The method under which the large companies are administered, the aims they follow, the interests adhered by the managers are obviously of critical importance. Such issues have been subject to academic interest from the early years of twentieth century and are more explicitly relevant today.

The original purpose of companies has always been one of the central concerns of corporate law. As the dominance of the economic approach to corporate law gained popularity, a prevailing stream of academic and legal voices has accepted "shareholder primacy," the view that fiduciary duties demand 
from managers to increase the shareholder wealth and prevent them from taking independent consideration of the interests of other constituencies. In 1919 the idea of value maximization for shareholders was accepted in a decision by the Michigan State Supreme Court in Dodge vs. Ford Motor Company. The decision of the company to divert substantial part of its retained earnings to new investments instead of distributing it to shareholders served as a ground for The Dodge brothers, minority shareholders in Ford Motor Company to bring suit against Ford, claiming that the intention to benefit employees and consumers was at the expense of shareholders. The decision of the court was in favour of claimants [13]. It was stated that creating value for shareholders should be the primary purpose of the company.

The process also continued in the 1970s when crucial statements were made by Chicago School of free-market economists. Famous members of the School started to claim that economic analysis was able to reveal the real goal of corporate governance. It was concluded that the company has to enrich its shareholders as much as possible. Nobel-prize winning economist Milton Friedman published in 1970 in the New York Times Sunday magazine an essay which further justified shareholder primacy. The essay claimed that since shareholders are owners of the corporation, the sole "social responsibility of business is to increase its profits [1].

Shareholder primacy can be defined as shareholder-centric way of corporate governance which prioritizes maximization of the value for shareholders over the interests of other corporate constituencies, namely society, local community, consumers, and employees [14].

The main justifications of shareholder primacy are:

1. Shareholder ownership. It is the conventional assumption that shareholders are the real owners of the company, and the managers are supposed to act in the best interests of the owners.

2. Residual Claim. Since the shareholders are entitled to the residual assets of the company after all other claims are fulfilled, it is suggested that by enhancing shareholder the overall social welfare is also provided.

3. The agency theory. This theory labels shareholders and directors as principals and agents respectively, and shareholder primacy is derived from the concept that agents must act in the best interests of principals [15].

4. Pragmatic justification stating that when managers are focused solely on shareholders, they are easily controlled, and conflict of interests are avoided [11]

Shareholder primacy approach is based on the assumptions that by creating value for shareholders, it is also possible to achieve the social goal and contribute to general wellbeing. This belief will be further discussed in the following paragraph. Moreover, shareholder primacy gives the managers a narrow group of interests to follow. Beyond alleviating the tasks of managers, it also prevents them from pursuing their own interests. Furthermore, compensation packages which are tied to stock prices can incentivize the managers for a better performance [12].

The approach could stand out also owing to its simplicity. It was much easier for the general public to understand the simple description of the compa- nies and their role. Moreover, by prioritizing the interests of shareholders, it was easier to tie every corporate fail to the selfishness of managers. Reducing the power of managers and giving the shareholder more power was an easy way of solving many business problems by lawmakers [9]. Shareholder primacy reached its peak of credibility in the early 2000 s.

"There is no longer any serious competitor to the view that corporate law should principally strive to increase long-term shareholder value. This emergent consensus has already profoundly affected corporate governance practices throughout the world. It is only a matter of time before its influence is felt in the reform of corporate law as well" [5].

It was regarded as a norm, as a dogma according to which companies should be governed. There was a little room for doubt that the genuine purpose of the company is maximization of shareholders' wealth.

\subsection{Gradual paradigm shift from share-} holder primacy

The arguments in favor of shareholders as residual claimants motivates to say that they seemingly deserve to be the main subject of fiduciary duty. This was the view accepted by scholars and transferred by them to future CEOs. It was a longstanding paradigm that the sole purpose of a firm is to make shareholders wealthier, grant them wider control rights, reduce agency costs between shareholders and managers.

A very appealing on the surface statement that residual claimant position of the shareholders guarantees overall social welfare provokes several questions. Is it a really effective way of achieving the real mission of companies? Can both shareholders and other constituencies actually benefit from it? Do shareholders by being residual claimants facilitate stakeholder value? If so, why big companies adhering to shareholder primacy failed to advance social welfare? The suspicion is exacerbated by the absence of credible empirical advantage of shareholder primacy. The Enron case where the managers were blindly trying to increase the shareholder wealth ended up with embarrassing liquidation [10], or the Deepwater Horizon disaster when the company trying to reduce the expenses at the cost of safety caused damage calculated in billions to the company and shareholders as well [13] are only a few of pitiable results of corporate misbehaviour.

A shift from one paradigm to another occurs when the original one is unable to respond to the anomalies happening and more progressive and efficient concepts are developed [3] and the same is going to happen with shareholder primacy. Modern-day studies are more and more inclined to reveal the wider mission of companies. It is getting clear that firms are not just instruments for profit-making. Short-termism is being regarded as a serious danger for financial health of the company. Sustainable and long-term development duly taking care of all corporate constituencies is gaining popularity.

"The shift is as fundamental and as necessary as the shift from a geocentric to a heliocentric view of the universe. Just as you can't "mend" the geocentric viewpoint, so you can't "mend" the shareholder value theory. It has to be transformed into a more accurate paradigm of the world. Because the shift is more profitable, the change in paradigm is now inevitable. Firms that don't make the shift will have dif- 
ficulty surviving. It's not a question of whether the change will happen. The only question is when" [17].

Obviously, the appealing and longstanding notion of shareholder primacy and the justifying position of shareholders as residual claimants fail to provide a sound framework for corporate governance. Seemingly certain position of shareholder primacy theory for the beginning of the 21st century is declining in credibility, and an increasing number of scholars is calling for profound research of this field. Almost all arguments justifying shareholder primacy, such as "shareholders own the company" [7], reduced agency costs [6] are facing criticism and labelling as "naked assertions".

Inferior position of shareholders in comparison to contractual claimants arises scientific distrust. A deep analysis of internal and external analysis reveals that the assumption about residual claimants of the company might not be flawless. Other constituencies also bear the risk to find themselves in the position of residual claimant. Often contracts fail to provide rock-solid guarantee for the claim, bargaining is not always equal, some specific investments bear more risk than those of shareholders.

Conclusion. Considering the vital role that businesses play in out modern-day world, it is particularly important to define the equitable approach to their governance. Shareholder value approach has long been used and appreciated by many corporate scholars. The theory has permeated most of the decisions made by the companies and legislators. Yet, it fails to prove itself as the most reliable way of governing the company.

Company Law and the understanding of corporate reality is constantly being altered to reflect the actual reality of modern-day world. Obviously, the paradigm shift is provoked by a clear view of the fact that companies do have social obligations and responsibilities apart from profit-making and expansion. Apparently, the trend leads to the inevitable and necessary sustainable way of doing business.

\section{References:}

1. Andrew R. Keay, Shareholder Primacy in Corporate Law: Can it Survive? Should it Survive? (November 1, 2009). Accessed September 2, 2019. Available at SSRN: https://ssrn.com/abstract=1498065 or http://dx.doi.org/10.2139/ssrn.1498065

2. "BP Lost 55\% Shareholder Value after the Deepwater Horizon Incident." 2014. Market Realist. September 10, 2014. Accessed September 12, 2019: https://articles2.marketrealist.com/2014/09/bp-lost-55-shareholder-valuedeepwater-horizon-incident/

3. Emrys Westacott. 2019. "What Is a Paradigm Shift?" ThoughtCo. October 12, 2019. Accessed September 12, 2019: https://www.thoughtco.com/what-is-a-paradigm-shift-2670671

4. Harry McCracken. "Amazon's Wild 24-Year Ride, from 11 Employees to 600,000-Plus.” Fast Company. Fast Company, April 11, 2019. Accessed September 2, 2019. Available at: https://www.fastcompany.com/90331689/ amazons-wild-24-year-ride-from-11-employees-to-600000-plus

5. Henry Hansmann, and Reinier H. Kraakman. The End of History for Corporate Law (January 2000). Yale Law School Working Paper No. 235; NYU Working Paper No. 013; Harvard Law School Discussion Paper No. 280; Yale SOM Working Paper No. ICF - 00-09. Accessed September 4, 2019. Available at SSRN: https://ssrn.com/ abstract $=204528$ or http://dx.doi.org/10.2139/ssrn.204528

6. Jill E. Fisch. "Measuring Efficiency in Corporate Law: The Role of Shareholder Primacy" (2006). Faculty Scholarship at Penn Law. 1043. Accessed September 15, 2019: https://scholarship.law.upenn.edu/faculty_scholarship/1043

7. John Kay. 2015. "Shareholders Think They Own the Company - They Are Wrong." Financial Times. Financial Times. November 10, 2015. Accessed September 15, 2019: https://www.ft.com/content/7bd1b20a-879b-11e5-90de-f44762bf9896

8. Laura McCamy. 2018. "Companies Donate Millions to Political Causes to Have a Say in the Government-Here Are 10 That Have given the Most in 2018." Business Insider. Business Insider. October 13, 2018. Accessed September 2, 2019. Available at: https://www.businessinsider.com/companies-are-influencing-politics-by-donating-millionsto-politicians-2018-9\#soros-fund-management-5

9. Lynn A. Stout. The Shareholder Value Myth: How Putting Shareholders First Harms Investors, Corporations, and the Public. San Francisco: Berrett-Koehler, 2013.

10. Margaret M. Blair. Shareholder Value, Corporate Governance and Corporate Performance: A Post-Enron Reassessment of the Conventional Wisdom, Oxford University Press, January 2003. Accessed September 11, 2019. Available at SSRN: https://ssrn.com/abstract=334240 or http://dx.doi.org/10.2139/ssrn.334240

11. Olivier, Weinstein. The Shareholder Model of the Corporation, Between Mythology and Reality Accounting, Economics, and Law: A Convivium, De Gruyter, vol. 3(1), pp. 43-60. Accessed September 4, 2019. Available at SSRN: https://ssrn.com/abstract=1498065 or http://dx.doi.org/10.2139/ssrn.1498065

12. Peter Cornelius and Bruce Mitchel. Kogut. Corporate Governance and Capital Flows in a Global Economy. 2003. P77. New York: Oxford University Press.

13. "Royal Dutch Shell Revenue 2005-2018." Statista. Accessed September 2, 2019. Available at: https://www.statista.com/ statistics/268734/revenue-of-royal-dutch-shell/

14. "Shareholder Primacy - Definition and Theory of Shareholder Primacy." n.d. Corporate Finance Institute. Accessed September 3, 2019. Available at: https://corporatefinanceinstitute.com/resources/knowledge/other/what-is-shareholder-primacy/

15. "Shareholder Primacy Theory Summary." Law Teacher. Accessed September 3, 2019. Available at: https://www.lawteacher.net/free-law-essays/business-law/chapter-shareholder-primacy-theory-summary-lawessays.php

16. The Primacy of Shareholder Interests: A Historical Perspective. Accessed September 2, 2019. Available at: https://saylordotorg.github.io/text_corporate-governance/s04-04-the-primacy-of-shareholder-int.html

17. "Taking the Long View." 2012. The Economist. The Economist Newspaper. November 24, 2012. Accessed September 12, 2019: https://www.economist.com/node/21567062/comments

18. "Walmart Revenue 2006-2019: WMT." Macrotrends. Accessed September 2, 2019. Available at: https://www.macrotrends.net/stocks/charts/WMT/walmart/revenue 